\title{
The 'making' of Europe in the peripheries: Europeanization through conflicts and ambivalences ${ }^{1}$
}

\author{
Susann Worschech (worschech@europa-uni.de) \\ European University Viadrina Frankfurt (Oder), Germany
}

In the social sciences, the idea of Europeanization as a pathway to an ever closer European Union and deepened integration is not uncontested, though it is still a popular concept. However, a paradigmatic turn towards a conflict-theoretical idea of Europeanization that is capable of taking into account the fuzziness and ambiguity of 'making Europe' is still wanting. In this article, I argue that Europeanization has never been unilinear and teleological but consists of ambivalences, turbulences, crises and simultaneous interlinked and contrary processes on transnational, national and subnational levels. Based on different theoretical strands of thought on social change, in particular Charles Tilly's political process model, I elaborate both this turn and a concept in three theoretical propositions that are based on one another and that constitute a systematically conflict-oriented concept of Europeanization. I illustrate the explanatory and analytical potential of the concept with an example that stands for ambivalent Europeanization processes beyond the EU's heartland: Ukraine. This view from the peripheries makes visible the need to analyze Europeanization as a multifold process involving inherent contradictions.

Key Words: Europeanization, transnationalism, conflict theory, Ukraine, post-socialist Europe, ambivalence, political process model

\section{Introduction: Ambivalent Europeanization - Concepts of Europeanization and mo- dernity}

"During the last seventy years, Europe failed again and again, in multiple forms. Thereby, it learned to fail better. Europe's failures did not signify the end of Europe, they even turned into components of Europe's success." (Ivan Krastev, 2018; author's translation)

With this provocative thesis, the Bulgarian intellectual Ivan Krastev challenges one of the most powerful and central narratives of modern Europe: the story of Europeanization as a linear and teleological process of an ever-growing coalescence of European societies. For decades now, Europeanization has stood for the homogenization and increasing convergence of political, economic and societal characteristics among European countries. Europeanization appeared to be a one-way street leading towards common policies of peace

\footnotetext{
${ }^{1}$ I would like to thank Timm Beichelt, Clara Frysztacka and Claudia Weber, all of whom are members of the research group "Ambivalences of Europeanization" at the European University Viadrina in Frankfurt (Oder), Germany, for inspiring discussions and ideas on new conceptions of Europeanization. I am also very grateful to Lauren Wolfe for her help with English language editing. This publication was supported by the Viadrina Institute for European Studies (IFES).
} 
and security, liberal democratic systems, Western welfare-state models and at least a basic canon of a shared European self-image. In particular, the term 'Europeanization' became more or less synonymous with 'extending and deepening EU integration'. Consequently, Europeanization beyond EU integration seemed to be a contradiction in terms.

From this perspective, the seriousness of and shrinking intervals between recent crisis phenomena that concerned and obviously shocked Europe's unidirectional development can only be seen as a serious threat to Europeanization. Crises are perceived as deviations from the 'normal' integration model. The plurality and mutual overlap of transnational crises that we witnessed during the last decade - the financial and economic crisis, the Ukraine crisis, the Crimea crisis, the migration crisis, the crisis of democracy and legitimacy and the Brexit crisis, to name only the most prominent crises - seem on their way to culminating in a final breaking apart of the Union and, consequently, of 'Europe'.

But what if we were to change our perspective and conceptualize crises as inherent elements of Europeanization? What if crises, usually seen as triggers of disintegration processes - which are themselves often perceived in the same linear and unidirectional way as integration processes - were to be seen as catalysts of further Europeanization? What if disintegration and integration were not assumed to be antagonistic processes but entangled and mutually thriving elements of Europeanization?

It is indicative that the idea of understanding failure as a core element of Europeanization is being promoted by a Southeastern European intellectual. In Europe's and the EU's eastern peripheries, both homogenization and fracture have occurred, often side by side, over the last decades. Poland, for example, was often considered a top student of European integration, even as the very efforts to converge with the Acquis Communautaire helped the first Eurosceptic coalition succeed in 2005. In Ukraine, the Euromaidan's slogan 'EUkraine' was accompanied by escalating violence from the state, which only reinforced protesters' hopes for Ukraine 'becoming a European country', accompanied by their claims that in Kyiv, Ukrainians would 'die for Europe's very own values'. ${ }^{2}$

The idea of failure, ambivalences and conflict as inherent elements of Europeanization is not quite new - neither empirically nor theoretically. More than one hundred years ago, Georg Simmel was the first to underline the potential of conflicts for sociation. However, within the context of Europeanization, the idea needs conceptual clarification. The mutual dependency of integration and disintegration, the inherent ambivalences and the role of tipping points need to be embedded in our understanding of Europeanization. This article aims at reviewing the status of failure, conflict and disintegration in studies and processes of Europeanization and proposes a conflict-based perspective on Europeanization.

The article proceeds as follows. First, I present a brief overview of pertinent research strands on Europeanization and discuss their shortcomings as well as their possible connecting points for a conflict-oriented conceptual turn. Second, I elaborate this turn by formulating three theoretical propositions, based on one another, that constitute a systematically conflict-oriented concept of Europeanization. Third, I illustrate the explanatory and analytical potential of my concept with the example of Europeanization processes in Ukraine.

${ }^{2}$ Claims, slogans and estimations based on the author's own long-standing scientific observation of Poland and Ukraine. 


\section{Conflict theory and European studies: Theoretical perspectives}

\subsection{Europeanization}

In political science, Europeanization for a long time was and still is interpreted as the impact of politics at the EU level on political processes at the national level of European countries. Europeanization encompasses varieties of political change caused by processes of European integration (Börzel \& Risse, 2003; Vink, 2003). Beichelt $(2015,4)$ notes that in classical political sciences, Europeanization started as a spinoff concept from the broader approach of (European) integration, describing a political dynamic of orienting domestic politics, expectations and loyalties towards a new - EU-European - center. The focus on Europeanization as domestic reactions to EU processes includes changes in external and internal border regimes, in domestic institutions, governance models, and linkages (ibid.), or compares domestic adaption to EU processes in the context of divergent domestic conditions (Risse, Cowles \& Caporaso, 2001). In the meantime, Europeanization as a bidirectional dynamic between the national and supranational level gradually received more attention. As Beichelt $(2015,28)$ argues, a constructivist perspective on Europeanization which was proposed by Radaelli (2003) emphasized the construction, diffusion and institutionalization of both formal and informal norms, institutions and styles. Europeanization was increasingly regarded as an intertwined transnational process of both top-down and bottom-up influences and changes of political, societal and economic frames, rules and practices related to the European Union and Europe as a spatial entity. Given the idea of mutual influence and interdependence, the constructivist perspective obviously questions the teleology and unidirectionality that had been inherent to most Europeanization concepts. But still, the conception of Europeanization as a vertical process of institutional convergence remained a dominant approach (Mérand, 2012, 217).

Empirically, Europeanization became a synonym for EU integration based on two phases of fundamental change. During the first four decades after the Second World War, European integration had been a step-by-step journey towards a contractual partnership among several European countries. In the early 1990s, integration strongly increased in terms of quality, density and speed. The rapid succession of the wide-ranging treaties of Maastricht, Amsterdam, Nice and Lisbon and the determination of future accession criteria (the Copenhagen criteria) cemented two central aspects of Europeanization: First, 'Europeanization' became virtually nothing else than the journey towards an ever closer union - and thereby, the idea of history as open-ended, which seemed apparent after the changes of 1989/91, narrowed to a linear and teleological path. Second, Eastern European countries had strong incentives to align themselves exactly with that path because of the now highly formalized accession process. The EU's conditionality exerted serious pressure on candidate countries to adapt their practices and regulations, political and economic systems to the EU's standards - which boosted modernization in these countries enormously but put them in the position of running breathlessly behind. This marks one of Europe's failures, as described by Krastev - the 'new' Eastern and Southeastern EU member states had and still have the feeling of lagging behind and never arriving. For them, Europeanization rather resembled a 'forced' alignment to exclusive conditions without much self-determination.

However, reality shows that there is more diversity beyond the 'ever closer Union' narrative. The political trajectories of the post-socialist accession countries in East-Central and Southeastern Europe demonstrate a huge heterogeneity. As Börzel and Schimmelfennig (2017) argue, these countries have shown overall improvement in democratic government over the last 20 years, but also different subregional paths and the decreasing influence of 
'core Europe' on political trajectories became obvious. While the EU's accession conditionality demonstrated a robust effect on governance effectiveness and democratic rule, "the EU's ability to promote EU norms and rules [was] reduced after the carrot of membership was consumed" (Börzel \& Schimmelfennig, 2017, 292). 'Europeanization' understood as convergence and homogenization of EU norms, rules and practices might be weakened once a country receives EU membership. The European Neighbourhood Policy (ENP), constructed in a similarly teleological manner but generally lacking the membership carrot, reveals a persistent heterogeneous puzzle of convergence and non-convergence in the mainly post-Soviet countries: Compliance with the EU's democracy and governance standards depends on the credibility and consistency of the Union in rewarding progress and sanctioning non-compliance (Börzel \& Lebanidze, 2017). The selective use of the EU's instruments to promote compliance leads to differing and often even contradictory patterns of norms, rules and practices of convergence beyond the EU's borders. From a macro perspective, Ukraine, Georgia and Tunisia, for example, largely adjusted their governance models and rules to the EU's conditions, while other ENP states such as Armenia or Jordan did not show democratic progress, due inter alia to the EU's ineffective use of conditionality (ibid.).

These empirical investigations yield valuable insights on different approaches of the EU in promoting convergence and on different patterns of compliance, but they stick to the idea of Europeanization as a linear process involving countries' adjustment to 'European' rules. Divergent developments and failures are interpreted as pathologies and deviations from the path of Europeanization. This perspective masks out that Europeanization could be a multifaceted process of compliance and non-compliance, involving integrative and disintegrative elements at the same time. Burlyuk and Shapovalova (2017) show that in Ukraine, 'Europeanization' clearly failed when it was implemented as a political bargaining tool with the Yanukovych regime, but it succeeded in mobilizing and empowering domestic players - which happened as an unintended consequence of conditionality. This underlines that if the inherent teleology of Europeanization concepts were broken up, then the ways we evaluate transformation processes in European societies could include systematic investigations of heterogeneity and inquiries into the impact of divergence and unintended consequences. Therefore, my first proposition is that Europeanization is a multidirectional, non-teleological process of social, political, economic and cultural transformations in and among European societies, based on but not determined by historical trajectories in Europe. This process is 'European' in the sense that it occurs in a particular context of institutionalized transnationalism that is inherent but not restricted to the institutional order. The EU's institutional order provides a unique setting that both enables and constrains these transformations and processes within institutionalized transnationalism in a way that balances heterogeneity and commitment of those involved.

\subsection{Crisis, conflict and Europeanization}

Refusing the integration paradigm does not necessarily imply a refusal of Europeanization theory per se, and I do not agree with lan Manners's $(2003,67)$ statement that "[...] there is no 'European theory'. And perhaps there should not be". However, Europeanization theory beyond integration requires an approach that a) regards the multifold and partly ambiguous processes below the structural macro-level and b) rejects the dualisms of integration vs. disintegration, adaption vs. peculiarity and the like, while maintaining the idea of a particular institutionalized transnationalism. Concerning the first requirement, a growing body of literature underlines the multifold horizontal processes of Europeanization, which 
are conceived as the core of sociological approaches to Europeanization (Pernicka \& Lahusen, 2018). In particular, the concept of social fields based on Bourdieu's field theory, Weber's value spheres or Fligstein's Strategic Action Fields, moved to the fore of the debate on the societal component of Europeanization (Bernhard \& Schmidt-Wellenburg, 2012; Kauppi, 2012; Lahusen \& Pernicka, 2016; Mérand, 2012). Within this emerging paradigm, research has been focusing on the emergence of a European civil society and solidarity across Europe (Lahusen, Kousis, Zschache, \& Loukakis, 2018; Liebert \& Trenz, 2009) and on transnational communication and public spheres (Büttner, Leopold, \& Mau, 2016; Eder, 2010; Liebert \& Trenz, 2011). Anthropological research on Europe analyzed communicative practices and the particular habitus of EU bureaucrats (Lewicki, 2017), since the EU "does not do anything on its own", but people are 'making' Europe, as Kauppi (2012, 233) argues.

Since Bartolini's (2005) influential work on Europeanization as a process of political structuring beyond the nation state, the fundamental change of borders in their appearance and functions in the context of Europeanization is increasingly addressed (Bach, 2010). Studies focused, inter alia, on the transnationalization of inequalities in Europe (Bach, 2016) and on European identity construction in absence of the classic foundations of the nation-state (Bach, 2015; Eigmueller \& Mau, 2010). Further, Europeanization based on dominant narratives and models about how to understand 'Europe' or 'European values' has been described with respect to European funding practices in the fields of research support (Büttner, Mau, Zimmermann \& Oeltjen, 2018) and of external democracy promotion in the EU's neighborhood (Worschech, 2018). These studies reveal the relevance of 'speaking the donor's language' and the impact of narratives and key words on perceptions of 'what is European'. They also underline the ambivalence of the beneficiary's abilities to use multivocality towards supporters (Padgett \& Powell, 2012) and to develop own narratives.

Concerning the second requirement - Europeanization beyond dualism - the literature on unintended effects of Europeanization and its (external) promotion (see also Hahn-Fuhr \& Worschech, 2014; Worschech, 2018) demonstrates not only the empirical plurality of Europeanization paths but also the innovation potential of divergence and non-conformity. In particular, historians have been pointing at the problematic conceptions of Europeanization that limit the process to EU integration. As Hirschhausen and Patel (2010a, 2010b) argue, historical-scientific research does not conceptualize Europeanization as a uniform, linear and targeted process that is restricted to particular geographical boundaries, but consists of processes of imitation, exchange and interrelations that either push or relativize European connections and similarities and that often correlate with other macro-processes of social change.

Consequently, in shifting away from teleology, ambivalences and crises become more interesting, not as disturbances but inherent elements of Europeanization. As Agh (2016, 278) notes, "[...] the EU has always been in 'crisis', it comes from its 'sui generis' nature of being always 'in the making' [...]. In this respect, the 'crises' are the natural ways of development for the EU". Crises are integral parts of Europeanization - as triggers, indicators, accelerators or effects. Crises can be understood as moments in which contradictory narratives or processes culminate. Therefore, they mark particular points in which ambivalences become apparent and processes may be turned in one or another direction. 
It is therefore surprising that conflict theory, although already inherent to many sociological approaches of Europeanization (see, for example, Fligstein, 2008), has not been systematically linked to Europeanization studies. As Europeanization obviously marks a particular form of societal and political change, conflict, contestation and crises are more than side effects - they are at the core of any transformation dynamic. In what way might conflict theory help to conceptualize a non-teleological idea of Europeanization?

Since the 'rediscovery' of Georg Simmel's brilliant essay on 'the dispute' in the early 1950s, the sociological perception of conflict has changed from disruption to sociation. Thanks to Lewis Coser, Simmel's theses on the social function of conflict have been further elaborated and integrated into our understanding of society. As social orders are lacking an 'ultimate end' towards which they may orient their development, dynamic and contestation are omnipresent. Any stability appears to be a temporal compromise between competing groups and segments of society (Joas \& Knöbl, 2004, 270ff.). Scholars such as Coser, Dahrendorf and Bendix stress the integrative potential of conflict that contributes to group evolution, identity construction, interest representation and negotiation. Conflicts remain dysfunctional if the social system does not allow for negotiation, whereas they become integrative in cases when normative expectations are visible, accessible and thereby negotiable (Coser, 1956). Further, scholars emphasize the content that conflicts relate to: 'nonrealistic' (Coser) or 'indivisible' conflict over, for instance, issues of ethnicity, culture, identity or absolute power need to be transformed into divisible distributional conflicts in order to become functional for the evolution of social orders.

With respect to Europeanization, society formation through conflict comprises a structural, an institutional and a cognitive dimension in addition to a basic divisibility (Fehmel, $2015,2017)$. Overlapping affiliations, the acceptance of procedural rules and conflict frames and the individual framing of the conflict issue determine the societal consequences of conflicts. In all three dimensions, disintegrative paths of social closure and content transposition are possible.

One main problem for European studies is that the dualism of integration and disintegration is retained, although under a different sign. Not convergence and adjustment but conflict (and its possible solution) leads to integration. Europeanization is conflictive but still ultimately a process of establishing shared rules, norms and practices. Disintegration persists as long as a common frame of conflict is not found (Fehmel, 2017) or as long as rational dissent, thus the decoupling of the content from the process of an argument (Miller, 1992), is not possible. The transformation of conflicts into distributive, transient conflicts is a normative target and, from this perspective, a proper contribution to Europeanization. Probably the most constructive conflict-oriented approach to analyzing Europeanization below the structural level and beyond dualism stems from scholars of the 'New Historical Sociology', and most significantly, from Charles Tilly. The titles of Tilly's books - European Revolutions; Big Structures, Large Processes, Huge Comparisons; Dynamics of Contention, to name only a few - do not appear to indicate small-scale analyses. Indeed, Tilly extensively stresses the role that revolutions, social movements, protests and violent collective action have had for Europeanization. But Tilly underlines the necessity of explaining 'episodes' such as large Europeanization phenomena by identifying robust mechanisms as a "class of events that change relations among specified sets of elements in identical or closely similar ways over a variety of situations" (Tilly, 2001, 26). 
Mechanisms can be classified as externally generated environmental mechanisms, as cognitive mechanisms of individual and collective perceptions and as relational mechanisms that alter connections among people, groups and interpersonal networks. Frequently occurring combinations or sequences of mechanisms are called processes in Tilly's approach and mark the relevant aggregated unit of analysis: "[P]olitical scientists should concentrate their explanations on selected features of episodes [...] or on recurrent processes in families of episodes [...]. In either mode, explanation consists of identifying crucial mechanisms and their combination into transforming processes" (Tilly, 2001, 37). Unfortunately, neither Europeanization studies nor the more recent European Studies have substantially expanded on Tilly's processual approach. This is astonishing, as one of the core ideas of Tilly's (and also Theda Skocpol's) understanding of Europeanization is that ruptures and fragmentation are central components of European modernization, and Europeanization cannot be explained plausibly without regarding the dynamics of political conflicts on the societal micro- and meso-levels of environment, cognition and relations.

How can a conflict-oriented, non-teleological and non-dualistic conceptualization of recent Europeanization benefit from Tilly's approach? I argue that instead of focusing on Europeanization as an 'episode' (in Tilly's words), we should rather try to identify the multi-layered, partially concurrent and contrasting mechanisms and their combinations that indicate Europeanization. My second proposition reads as follows: Europeanization consists of a plurality of concurrent environmental, cognitive and relational mechanisms that occur as sequences and combinations (=processes). These processes comprise contradictions, conflicts and ambivalences as core elements because of the plurality and non-determination of the mechanisms that form their basis.

Starting from this proposition, two aspects should be further elaborated. First, it needs to be clarified how this proposition relates to Europeanization concepts that emphasize the construction, diffusion and institutionalization of both formal and informal norms, institutions and styles, and the convergence with EU norms and practices (Radaelli, 2003; Vink, 2003). I argue that these aspects can be integrated in Tilly's mechanisms-and-processes model.

Institutions and rules belong to the same group of social phenomena, namely the stabilization of reciprocal and mutually expectable social actions that is called 'institutionalization' (Berger \& Luckmann, 1980). Social or organizational institutions form an environment that constrains or enables social action. The environmental mechanisms of the political process model can be affiliated with institutions and rules.

Both static definitions of Europeanization include norms as objects of change. But norms are always matters of negotiation and social construction. To capture norm change in the political process model, it is valuable to look at how norms are perceived, interpreted, contested and altered - thus, to analyze individual and collective cognitive mechanisms for building scripts and frames (Benford \& Snow, 2000; Esser, 2001, 263). This allows for the integration of the contingency and context-sensitivity of both scripts and frames, while accepting them both as results of intersubjective construction and guides to social action. Finally, both definitions mention styles and practices. Practices are obviously relational actions because they are "socially meaningful patterns of action" (Adler-Nissen, 2016, 88). They are the smallest units of the social world: a routinized nexus of doing and saying things, and "skillful performances" (Reckwitz, 2003) which are based on social embeddedness, intersubjective understandings and interlinkage. Relational sociology links mean- 
ings, stories and understandings to relational practices and argues that structures of meaning are built upon the relational positioning of actors in multi-layered networks (Fine \& Kleinman, 1983; Fuhse, 2009; Mohr, 1998). Consequently, styles and practices can be understood as elements of relational mechanisms in Europeanization processes.

To sum up, conceptions of Europeanization focusing on norms, institutions/rules and styles/practices can be translated into Tilly's political process model that emphasizes environmental (institutional), cognitive (normative/frame-oriented) and relational (styleand practice-oriented) mechanisms.

Second, since it appears plausible to agree that Europeanization is a conflictive process, although it remains difficult to conceptualize meaning and impact of conflict beyond the integration/disintegration dualism, we should pay more attention to the idea of ambivalences. From the perspective I propose here, ambivalences are the most promising concept for capturing the fuzzy back-and-forth character of the multitude of entangled, co-occurring and potentially contradicting mechanisms of Europeanization. The next section proposes an analytical integration of ambivalences in Europeanization.

\subsection{Ambivalences of Europeanization}

The notion of the conceptual importance of ambivalences in the explanation of social change is attributable to Zygmunt Bauman, who made it an outstanding term for understanding the complexity and potential contrariness of modernity.

Ambivalence, ambiguity and disorder are driving forces of modernity. Modernity itself consists of the promise to provide order and clarity, thus the core of modern culture implies an ongoing yet desperate fight against ambivalence. As complexities increase, Bauman argues, this fight becomes the constitutive factor of modernity. At the very moment when the perception of ambivalence shifts from the antagonism of modernity to a productive force that unleashes new opportunities and freedoms, that is when a postmodern societal order emerges (Bauman, 1991, 2000). In his writings on Postmodernity and its Discontents (Bauman, 1997), Bauman underlines that postmodern societies face high insecurity due to a profusion of freedom. The struggle with ambivalences and disorders that results from this expanded freedom devolve onto the individual, who is confronted with the general failure of societal and cultural re-organization.

Following Bauman, ambivalence is an essential feature of modern and postmodern societies, a driving force and at the same time a result of attempts to establish societal or cultural orders. The concept of modernity and modernization itself is axiomatically linked to Europe and Europeanization, since historians usually index the beginning of the modern era or modernity and ideas of modernization to a shift in our thinking of temporality that took place in mid- $18^{\text {th }}$ century Europe. At that time, incipient industrialization and modernization included a new awareness of the discontinuity between present and past; for the first time the present was perceived as a transitional moment (Koselleck, 1973). In this context, the idea of a rupture with the past and a horizon of expectations for a 'better future' became the normative content of both the idea of modernity and the idea of Europe. 
Ambivalence as a core concept of modernization can be transferred to processes of Europeanization as well. The interdisciplinary research group 'Ambivalences of Europeanization' argues that these ambivalences appear in three dimensions of European sociation. In a social dimension, processes of homogenization and differentiation arise parallel, while in a spatial dimension, Europeanization consists of integrating and disintegrating border regimes and practices. Finally, a temporal dimension marks acceleration versus time shift and delay as ambivalent aspects of Europeanization (Beichelt, Frysztacka, Weber, \& Worschech, forthcoming).

But ambivalence implies more. It is a term that allows for a conceptualization of processes that lead to both integration and disintegration and to further consequences. If Europeanization is a multidirectional, conflictive and potentially fuzzy process (or episode), the underlying mechanisms can be expected to produce ambivalence. Cognitive framing mechanisms, environmental-institutional mechanisms and practice-oriented relational mechanisms may in their co-occurrence lead to results that contradict each other, and they may even produce inherently ambivalent outcomes.

Consequently, my third proposition (which can be understood as a synopsis of the two previous propositions and the above reflections on ambivalences) reads as follows: Europeanization consists of a plurality of concurrent environmental, cognitive and relational mechanisms of societal change that links the national or subnational levels with the transor supranational levels of European societies. The mechanisms occur in sequences and combinations and produce ambivalences between and within their realms. The particular Europeanization ambivalence consists of the specific contrary effects produced by all three mechanisms and consequently a simultaneity of integrative and disintegrative elements in institutional, framing and relational mechanisms and processes.

The next chapter on Europeanization processes in Ukraine illustrates these 'ambivalences of Europeanization' and shows how Europeanization as a political process model can be applied to empirical studies.

\section{Ambivalent Europeanization in Ukraine}

If a social scientist were in need of a stunning example of conflictive political processes, Ukraine would definitely make an excellent candidate for illustration. Since 1990, Ukraine experienced no less than three large (and quite a number of smaller) public uprisings which led to significant changes in the political system: the Human Chain for Ukrainian independence between Kyiv and Lviv, when 300,000 Ukrainians connected the two cities on January $21^{\text {st }}, 1990$; the Orange Revolution in November and December 2004, when as many as one million Ukrainians protested against election fraud and forced new presidential elections; and finally, the protests of winter 2013/14 which are commonly known as Euromaidan or Revolution of Dignity, when again mass demonstrations, the occupation of central squares in many Ukrainian cities and also violent conflicts with the regime's military forces finally led to political change. It is obvious that Ukraine's recent history is driven by conflict and contestation, what marks a continuity of Ukraine's longstanding history of protests, uprisings, dissidence and civil society activism dating back to the era of Soviet rule and even earlier. 
The empirical illustration focuses on the two most recent large uprisings, the Orange Revolution and the Euromaidan, as well as political processes and Europeanization attempts between the two events. I relate them to the theoretical concept of Europeanization as a plurality of concurrent transnational environmental, cognitive and relational mechanisms of societal change.

\subsection{Environmental/ institutional dimension and mechanisms}

The first category of Europeanization mechanisms focuses on homogenization or fragmentation, adoption or counteraction of rules and rule systems in a transnational context. The adoption of the EU's Acquis Communautaire, would mark one of these mechanisms, but since Europeanization is not a one-way street, there is more to say about the institutional dimension and its inherent ambivalences.

Ukraine's contribution to European modernization did not start with the country's independence in 1991 - it should not be forgotten that Soviet modernization was a part of Europeanization as well, although following a different path and adhering to different premises than Western Europe. As Minakov $(2018,22)$ notes, modernity is a project with particular spatial and temporal constraints and variance - Eisenstadt's Multiple Modernities could be refined and renamed Regional Modernities, of which Soviet modernity was a particularly influential one. Europeanization as a particular set of modernization forms in Europe is a part of Ukraine's recent history.

Since its independence, which is a first tipping point in Ukraine's history as a sovereign state, Ukraine underwent an intense dynamic of political openness and closure as well as different events involving transnational influences. At the end of the 1990s, President Leonid Kuchma intensified his attempts at turning Ukraine into an authoritarian state. Following the murder of the critical journalist Georgiy Gongadze, who had been reporting on high-level corruption, Ukrainian oppositions groups, strongly suspecting that president Kuchma himself had been involved in the murder, initiated street protests in Kyiv with about 10,000 participants in early 2001 (D'Anieri, 2006). But the protests failed to seriously threaten Kuchma's position, since the opposition remained divided and the reactions of Western countries and the European Union were reserved. However, the voices demanding a comprehensive resolution of the case never fell completely silent, what ultimately prepared the ground for the 2004 Orange Revolution. The sensitization of the population to the case of 'stolen elections' began a long time before the presidential elections, which were held in October and November 2004. Parallel, transnational networks of activists and pro-democratic youth organizations were established. The Serbian organization OTPOR! (Resistance!), already successful in organizing the protests against Slobodan Milošević in 2001, elaborated protest tactics and shared them with targeted Ukrainian activists (see sections on frames, relations and networks). The well-prepared campaign, together with a now united political opposition and increased attention from European Union members, opened a window of opportunity for successful protests and, finally, new elections which brought Viktor Yushchenko, a democratic and 'Western' oriented president, into office.

Until 2004, 'Europe' could not be termed a systematic issue in Ukraine's foreign politics, nor in societal debates. The EU and Ukraine had already signed a Partnership and Cooperation Agreement in 1992, but the four EU-Ukraine summits held between 1997 and 2000 did not bring substantial progress. As a consequence of the murder of the journalist, relations remained at a low level after 2000. A summit in Copenhagen in 2002 signified a possible turn on the part of Ukraine, when President Kuchma presented an ambitious plan 
involving Ukraine signing an association agreement with the EU by 2003-2004 and meeting all EU membership requirements by 2011 . The European Union reacted reservedly, establishing cooperation on rather low-level policy fields, while the idea of a European Neighborhood Policy was developed as an instrument to offer 'anything but membership' to non-EU countries after the EU enlargement 2004 and 2007 (The Ukrainian Week, February $28,2013)$. 'Europe', it seemed, had been used by Kuchma as an interim appeal or a distraction from the allegations against him in the Gongadze murder - the 'plan' which Kuchma presented never translated into reforms.

After the Orange Revolution, the new Western-oriented administration of president Yushchenko enjoyed much higher trust from the EU. Meanwhile Poland, as Ukraine's direct neighbor and now proponent within the EU, actively supported Ukraine's path towards the EU. 'Europe' became a fixed target for Ukraine's political path, which included institutional reforms, rule convergence and the elaboration of a comprehensive association agreement (in 2008). The European Union, for its part, expressed but also specified its interest in Ukraine's trajectory - by strongly encouraging Europeanization as convergence with its own standards.

Parallel to increased institutional alignment with the EU, the governing reform coalition in Ukraine faced heavy disruptions. In 2010, Victor Yanukovych - who had first 'stolen' and then lost the presidential elections in 2004/2005 - became president and immediately started an authoritarian restoration. 'Europe' was no longer the target of Ukraine's foreign policy, nor did the new administration continue the ongoing political reforms. A decoupling from the EU and from Ukraine's Western partners in general became obvious. While most observers expected Ukraine under Yanukovych to develop a multivectorial foreign policy of extending ties with both the EU and Russia, but to maintain pluralism and democratic institutions in Ukraine, the new president in fact changed the constitution to concentrate power in his hands. 'Democracy' and 'Europe' became merely rhetorical means and did not imply any specific policy of institutionalization or reforms. Notwithstanding this domestic autocratization, the association agreement with the EU was enhanced and ready to sign in late 2013 - a moment that Kuchma had already promised would happen ten years earlier though he never took serious steps in that direction.

The developments in Ukraine, beginning from late November 2013, are broadly known as 'Euromaidan' or, as Ukrainians call it, 'Revolution of Dignity'. A growing societal coalition of students, activists, pro-European party leaders and members and, increasingly, 'ordinary citizens' emerged in the wake of Yanukovych's repression of the first protests. The reason for these initial protests - Yanukovych's refusal to sign the association agreement with the European Union - only mobilized a few thousand students and activists, but then the violent attempt by the special forces to break up the protests brought the masses into the streets - and focused broad attention on the original problem: the question of Ukraine's future foreign policy direction. The critical moment that brought about changes in Europeanization came when Ukraine's government abandoned its 'traditional' foreign policy path of meandering between Russia and the West, and decided to orient its integration activities clearly in favor of one side - Russia (Dragneva \& Wolczuk, 2016).

The institutional processes in Ukraine since Euromaidan are much more oriented towards clear alignment with the EU's formal requirements, rules and procedures, although the ongoing conflict in eastern Ukraine, power struggles and fragile political coalitions render the 'European' course of reform difficult and fuzzy once again. 
To sum up, institutional mechanisms of Europeanization occurred in parallel and inversely. While throughout the 1990s, processes of institutional closure and de-coupling of rule systems occurred, the next decade brought opening and institutional alignment, followed by new closure in 2010. These processes were barely congruent, either because they were used to simulate Europeanization - as with Kutchma's schedule for Ukraine's EU integration - or they were not answered adequately by the EU. Ukraine's bidirectional diplomacy between the EU and Russia (Dragneva-Lewers, Wolczuk \& Dragneva, 2016) as well as the EU's indecisiveness towards Ukraine promoted fragile and divergent processes of institutional Europeanization.

\subsection{Framing/ cognitive dimension and mechanisms}

Just as the institutionalization process related to 'Europeanization' was not straightforward in Ukraine, the same is true of the collective framing of Europe. Before and during the Orange Revolution, Europeanization and closer political relations with the European Union were issues for experts, activists and often students, but they were not of further concern for a broader public. Issues underlying the Orange Revolution were free and fair elections, press freedom, freedom of association and opinion - all of which of course it may be argued are 'core values' of European democracies and of the EU as well, but they were not framed as such. More precisely: while the role of Europe and the EU was an important aspect in debates about Ukraine's future - since transnational civil society networks had been expanding and strengthening in the years before the revolution - 'Europe' was nevertheless not a systematic or relevant frame that was used for mobilization. Instead, the civil society groups that were the main drivers of the Orange Revolution - two groups called Black PORA and Yellow PORA (lit. "It's time!"), both founded by civil society activists who had been active since Ukraine's independence, as well as a number of student groups - thematized the relevance of voting, the danger of unfair elections and president Kuchma's authoritarian rule which they called kuchmizm. Both PORA groups combined political and civic activities, but their mobilization strategies especially were highly innovative. For the first time, humor and ridicule as well as music and carnivals were systematically employed for mobilization. Jokes proliferated about candidate Yanukovych's obviously fake academic title (his official CV nominated him "proffessor" with a double f) and about his frequent use of a rough slang; anecdotes about his criminal past circulated and made him the object of mockery - all of which changed the style of dealing with authoritarian closure and encouraged people to protest against it (Kuzio, 2006; Nikolayenko, 2007; Polese, 2009). But the PORAs were not the first to deploy these strategies - they refined and expanded the techniques the Serbian group OTPOR had developed to mobilize against Milošević. Based on OTPOR's targeted dissemination of new protest styles and issues, a common framing for fighting post-socialist attempts at authoritarianism evolved among East European activist groups.

One decade later, in the Euromaidan protests, protest frames were much more focused on Ukraine's closer cooperation with and possible integration into the European Union. European flags appeared all over the protest spaces, the EU's stars symbol was often combined with the Tryzub, the state coat of arms of Ukraine, which was placed at its center. The slogan 'EUkraine' could be seen quite often, and public intellectuals emphasized that the realization of the European idea was happening in Kyiv's Independence Square, the center of the protests (Prochasko, 2014). Although the government's refusal to sign the association agreement was the trigger for the protests, the 'Europeanness' of Ukraine understood as transparency, rule of law, democratic procedures, freedom and the separation of powers - were the real issues of the revolution. It can be argued that Yanukovych 
had broken the 'silent agreement' that he would be permitted to stay in office as long as he didn't too obviously diminish the openness towards the European Union.

The positive framing of 'Europe' needs to be set in context with the role of the European Union and the member states' organizations and embassies that engaged in democracy promotion in Ukraine. Since the Orange Revolution, there has been an increase in democracy promotion activities targeting civil society, democratization and 'Europeanization' (in a political sense). Donors and supporters have established programs on Europeanization, the representation of the EU Commission has organized festivals in several Ukrainian cities in honor of the annual Europe Day and exchange, research and cultural activities have been supported (for a detailed analysis of projects, programs, frames and resources, see Worschech, 2018). This is not to say that all these activities have been able to promote a single, positively connoted and unitary frame or picture of Europe and Ukraine's 'Europeanness'. Pro-European civic activists mindfully recognized that, while supporting the 'progressive, pro-European' civil society, most external donors were also cooperating with the authoritarian regime of president Yanukovych. This made clear that 'Europe' is more ambiguous than its proponents claimed.

But Europe remained a contested term even during Euromaidan. As Minakov (2018, 175ff.) analyzed, three narratives of Europe were present in the protests: First, Europe was conceptualized as an 'almost ideal place' where welfare and good conditions for personal development could be found, a place with good education and without corruption which Ukraine should be part of. Protesters interpreted Europe as a good place for their individual development, while at the same time doubting - even at Euromaidan - whether it would be the right path for Ukraine to take, as a society. The second narrative, which Minakov found expressed mainly among radical participants in Euromaidan, was Europe as 'Good, but not ours'. These participants obviously fought against a Russia-oriented path for Ukraine but stressed the relevance of Ukraine's authenticity and the particularity of Ukrainian identity. In particular, radicals taking part in the 'Antimaidan' protests shared a third narrative: that of Europe as a 'cunning enemy' that seeks to exploit Ukraine. These three simultaneously shared ideas of Europe signify the ambivalence vis-à-vis European utopias and the ambiguous framing of Europe even during the most popular 'pro-European' protests of recent years.

Interestingly, public opinion polls demonstrate that until the Euromaidan protests, Europeanization and closer ties with the European Union did not seem to play a major role among Ukrainian citizens. In 2006, about $30 \%$ of respondents to a representative survey answered that they somewhat or strongly support Ukraine's integration with the EU, while $56 \%$ supported an alliance with Russia and Belarus (KIIS, 2006). In 2012, support for Ukraine's association with the EU increased to 40\%, but support for the alliance with its eastern neighbors was still much higher (55\%) (KIIS, 2012). Between February 2013 and February 2015, support for Ukraine's association with the EU grew from $37 \%$ to $47 \%$, while the support for an alliance with Russia and other eastern neighbors in the customs union fell from $38 \%$ to only $13 \%$ (KIIS, 2015). The issue of establishing closer ties to the European Union was for a long time not highly relevant - in fact, most Ukrainians seemed to be rather indifferent towards that question until it entered more prominently into the agenda shortly before the Vilnius Summit in November 2013, when the association agreement should have been signed. In a survey taken November 9-20, 2013, 40\% of mainly younger respondents confirmed that they would support Ukraine's association with the European Union, while $41 \%$ of people primarily over 40 supported Ukraine's integration into the customs union (KIIS, 2013). These numbers changed dramatically only after the Euromaidan 
- as of today, a clear majority of $57 \%$ would like to see Ukraine become a full member of the European Union (KIIS, 2017).

To sum up, 'Europe' became a relevant framing for political targets only at the moment when the head of government broke a basic agreement with those he governed: by refusing to continue balancing two contradictory foreign policy orientations and refusing to continue the more-integrative-than-disintegrative path with its Western neighbors and the EU. In the course of the protests, 'Europeanization' was sometimes very enthusiastically framed as non-authoritarian rule, as 'dignity', as respect for human rights and basic freedoms. Writers described Ukraine as a place where people died for Europe's own values, a place where Europe was being 're-invented' and re-vitalized (Andrukhovych, 2014).

\subsection{Practice/ relational dimension and mechanisms}

Finally, the third category of mechanisms focuses on practices and styles as elements of social interaction. Transnational social networks and their inherently interactive practices are the third dimension of social processes that shape Europeanization. How did transnational networks evolve in Ukraine, and how do these phenomena relate to Europe?

With the Orange Revolution, a new phenomenon of transnational youth protest networks emerged in Central and Eastern Europe. OTPOR were the first to use highly innovative protest tactics to mobilize a broad part of society to rise up against authoritarian rule. Their methods - among them a clear framing, recognizable symbols such as a simple black fist, subversive and humorous actions and a non-hierarchical organizational form - were highly successful and easy to transfer at the same time. OTPOR, re-named CANVAS after the successful uprising, turned into a training center for protest groups in post-socialist authoritarian states. They wrote a political 'cookbook' on nonviolent struggle which entailed instructions on how to bring down your dictator. The book was translated in several languages and is free for download. OTPOR/CANVAS implemented trainings for Georgian and Ukrainian activists in Hungary to bypass Ukraine's security services, and advised the groups to establish protest and campaigning networks months before the presidential elections, which they expected to be unfair, were to take place. These strong transnational networks of exchange and advice on ideas, innovative tactics and nonviolent protest became the backbone of pro-democratic protests in Georgia in 2003 and Ukraine in 2004 (Kuzio, 2006). While protesters were successful in establishing a stable coalition between the civic movement and political parties on the protest site, this coalition was not successfully transferred into institutions. By contrast, the "leaders that came into power as a result of the color revolutions quickly accepted the term of the façade democracy game, did not lay the foundations for the development of democratic institutions, and reproduced the same model by which government decisions are made in the interest of a narrow circle of financial and political groups" (Minakov, 2018, 169). In Tilly's words, the pro-democratic coalition of the revolution did not manage to establish broad, equal, protected and mutually binding consultation between government and the governed (Tilly, 2007, 13f.). This lack of political inclusiveness marked the period between the two revolutions and paved the ground for Yanukovych's authoritarian restoration from 2010 onwards.

During this period, Ukrainian civil society was increasingly supported by democracy support activities from external - Western - donors. Relations and activities among civic groups and support agencies increased, but it is contested whether this support did actually contribute to the building of civic networks in Ukraine. Until late 2013, most scholars stressed the growing competition among civil society groups which found themselves in 
rivalry for funds and grants. Trust rated rather low among civic activist groups, but also between citizens and civil society organizations (Hahn-Fuhr \& Worschech, 2014; Lutsevych, 2013; Palyvoda, 2014; Palyvoda \& Golota, 2010). Surprisingly, when at Euromaidan the students' protests turned into mass protests as a result of the violent attempt to break up the protests on the $1^{\text {st }}$ of December, 2013, trust and solidarity between citizens and activists were quickly restored. This might be attributed to the fact that civil society organizations did not participate as 'organizers', nor did they themselves call for protest, but their skilled and experienced activists and professionals did help organize and maintain the protest infrastructure.

During the first weeks of Euromaidan, there was a clear divide between the 'civic' and the 'political' Euromaidan - the citizen protest camp refused to join forces and share space with the protest stage of the opposition parties. They were even located at two geographically separated squares in Kyiv's center. As Minakov $(2018,175)$ notes, "although the groups of protesters subsequently merged, the attempt at a clear-cut separation between 'citizens' and 'politicians' was symptomatic. [...] Utopian ideas regarding the possibility of radical changes in society, the economy, and politics are an inseparable part of the Euromaidan mass protests." Hence, relations were slowly reinforced among citizens and civil society activists but remained distant and conflictual with the political elite, which left the citizens and activists room for developing far-reaching 'European' ideas about Ukraine.

After Euromaidan, a certain share of activists and protesters entered political institutions. For example, 30 of the most prominent civic activists became members of the Ukrainian parliament, others started to work in the administration, often with the aim of changing institutions from within by inserting Euromaidan's ideals into political processes and decisions (Worschech, 2014, 2016). Euromaidan's self-organized groups and civic activities, for example the self-defense groups or the medical centers at the protest site, evolved into organizations and initiatives that continued their civic activities after the protests had ended (Worschech, 2017; Zarembo, 2017). This volunteer-based civil society which emerged from the Euromaidan marks a new quality in Ukrainian civil society, which heretofore had been largely lacking volunteer activism. On the ruins of Euromaidan's barricades emerged a sense of social responsibility, mutual trust and civic networks among citizens. These issues have been a central target for thousands of democracy promotion projects by external donors for some time - but in the end they were created only through collective conflictive action.

To sum up, relational mechanisms appear to be the least fragile and fuzzy phenomena in this case. Although several breaks, ruptures and cleavages among civic groups, activists, supporters and officials appeared, a sound trans- and subnational relational structure could be established. These patterns of interaction helped to form a social structure of positions, roles and communicative arrangements and thus a skeleton for transnational interlinkages as one aspect of Europeanization.

Taken together, Ukraine's Europeanization exhibits a plurality of contrasting elements within and between all three dimensions that result in particular ambivalences. The most obvious ambivalence can be found in the overlap of environmental or institutional elements of integration and disintegration: Closure and opening towards 'Europe' occurred alternately, but usually incongruently with rhetoric and framing. In that particular moment when mechanisms in both dimensions became congruent - the refusal of the association agreement as a decisive moment of institutionalization and framing - huge social change 
became possible, based on and boosted by established subnational, national and transnational social networks. As I argued above, Ukraine demonstrates that Europeanization comprises contrary effects and a simultaneity of integrative and disintegrative elements in institutional, framing and relational mechanisms and processes.

\section{Conclusion}

This article started with the notion that the common understanding of Europeanization resembles more of a one-way street than a tour with multiple bifurcations, paths, looping roads or bumpy trails. But, as Krastev makes clear, the 'Europeanization' of Central and Eastern Europe in particular demonstrates that failure, conflict and ambivalence are not disruptions but core elements of that process.

The particular ambivalence the Ukrainian case demonstrated stems from the simultaneity of potentially contradicting mechanisms related to institutions, frames and networks. The illustrative case shows that when Europe-related institutionalization and rules are at a low - as for example was the case on the eve of the Orange Revolution - strong transnational networks of European youth and student activist groups may be established. The framing of Europe as a relevant category for Ukraine's political path still remained at a low level notably during the period after the Orange Revolution, when significant steps towards cooperation and association between Ukraine and the EU were made. The final decision to leave the path of institutionalization which kept Ukraine meandering between both European- and Russian-oriented integration schemes produced a strong cognitive linking of Ukraine's future with 'Europe', 'European values and rules' and the European Union. In the case of Ukraine, the ambivalence of Europeanization takes the form of a striking asynchronicity in 'Making Europe' in the cognitive, institutional and relational dimensions.

To conclude, this article underlines that our thinking about European crises and paths of development may highly benefit from systematically integrating conflicts, contradictions and ambivalences in our conception of Europeanization. In accepting the ambivalent paths and outcomes of Europeanization, Western European countries may learn valuable lessons which they can apply to changes and potentially conflictive processes that they may have to face in their own societies in the near future. By keeping civic solidarity alive, and, as Tilly (2007) puts it, building networks of trust and ensuring broad, equal, protected and mutually binding consultations in social and political spheres, European societies might be better able to deal with the entangled, partly antagonistic and mutually thriving elements of Europeanization.

\section{References}

Adler-Nissen, R. (2016). Towards a practice turn in EU studies: The everyday of European integration. JCMS: Journal of common market studies, 54(1), 87-103.

Ágh, A. (2016). The deconsolidation of democracy in East-Central Europe: The new world order and the EU's geopolitical crisis. Politics in Central Europe, 12(3), 7-36.

Andruchovyč, J. I. (Ed.). (2014). Euromaidan: Was in der Ukraine auf dem Spiel steht. Berlin: Suhrkamp. 
Bach, M. (2010). Die Konstitution von Räumen und Grenzbildung in Europa: Von verhandlungsresistenten zu verhandlungsabhängigen Grenzen. In M. Eigmueller \& S. Mau (Eds.), Gesellschaftstheorie und Europapolitik: Sozialwissenschaftliche Ansätze zur Europaforschung (153-178). Wiesbaden: VS Verlag für Sozialwissenschaften.

Bach, M. (2015). Europa ohne Gesellschaft: Politische Soziologie der Europäischen Integration. Wiesbaden: Springer VS.

Bach, M. (2016). Unbounded cleavages. In M. Eigmüller \& G. Vobruba (Eds.), Grenzsoziologie: Die politische Strukturierung des Raumes (141-152). Wiesbaden: Springer VS.

Bartolini, S. (2005). Restructuring Europe: Centre formation, system building and political structuring between the nation state and the European Union. Oxford: Oxford University Press.

Bauman, Z. (1991). Modernity and ambivalence. Oxford: Wiley.

Bauman, Z. (1997). Postmodernity and its discontents. Cambridge: Polity Press.

Bauman, Z. (2000). Liquid modernity. Cambridge: Polity Press/ Blackwell.

Beichelt, T. (2015). Deutschland und Europa: Die Europäisierung des politischen Systems. Wiesbaden: Springer VS.

Beichelt, T., Frysztacka, C. M., Weber, C., \& Worschech, S. (forthcoming). Ambivalences of Europeanization: Modernity and European integration in perspective. (IFES Working Paper Series No. 1/2019).

Benford, R. D., \& Snow, D. A. (2000). Framing processes and social movements: An overview and assessment. Annual review of sociology, 26(1), 611-639.

Berger, P. L., \& Luckmann, T. (1980). Die gesellschaftliche Konstruktion der Wirklichkeit: Eine Theorie der Wissenssoziologie. Frankfurt a.M.: Fischer.

Bernhard, S., \& Schmidt-Wellenburg, C. (Eds.). (2012). Feldanalyse als Forschungsprogramm 2: Gegenstandsbezogene Theoriebildung. Wiesbaden: Springer VS.

Börzel, T. A., \& Lebanidze, B. (2017). "The transformative power of Europe" beyond enlargement: The EU's performance in promoting democracy in its neighbourhood. East European politics, 33(1), 17-35.

Börzel, T. A., \& Risse, T. (2003). Conceptualizing the domestic impact of Europe. In K. Featherstone \& C. M. Radaelli (Eds.), The politics of Europeanization (57-80). Oxford: Oxford University Press.

Börzel, T. A., \& Schimmelfennig, F. (2017). Coming together or drifting apart? The EU's political integration capacity in Eastern Europe. Journal of European public policy, 24(2), 278-296.

Burlyuk, O., \& Shapovalova, N. (2017). “Veni, vidi, ... vici? " EU performance and two faces of conditionality towards Ukraine. East European politics, 33(1), 36-55. 
Büttner, S. M., Leopold, L. M., \& Mau, S. (2016). Zwischen „der Eurokratie“ und „den Leuten": Zum Problem der professionellen Vermittlung von Europapolitik. Berliner Journal Für Soziologie, 26(1), 35-60.

Büttner, S. M., Mau, S., Zimmermann, K., \& Oeltjen, O. (2018). Benennungsmacht und Vokabular der EU-Governance. Zur symbolischen Macht der europäischen Forschungsförderung. Österreichische Zeitschrift Für Soziologie, 43(1), 37-63.

Coser, L. A. (1956). The functions of social conflict. New York: The Free Press.

D'Anieri, P. (2006). Explaining the success and failure of post-communist revolutions. Communist and post-communist studies, 39(3), 331-350.

Dragneva, R., \& Wolczuk, K. (2016). Between dependence and integration: Ukraine's relations with Russia. Europe-Asia studies, 68(4), 678-698.

Dragneva-Lewers, R., Wolczuk, K., \& Dragneva, R. (2016). Ukraine between the EU and Russia: The integration challenge. London: Palgrave Macmillan.

Eder, K. (2010). Die EU als entstehender Kommunikationsraum. Zum Theoriedefizit der soziologischen Europaforschung und ein Vorschlag, dieses zu verringern. In M. Eigmueller \& S. Mau (Eds.), Gesellschaftstheorie und Europapolitik: Sozialwissenschaftliche Ansätze zur Europaforschung (80-108). Wiesbaden: VS Verlag für Sozialwissenschaften.

Eigmueller, M., \& Mau, S. (Eds.). (2010). Gesellschaftstheorie und Europapolitik: Sozialwissenschaftliche Ansätze zur Europaforschung. Wiesbaden: VS Verlag für Sozialwissenschaften.

Esser, H. (2001). Soziologie: Spezielle Grundlagen. Band 6: Sinn und Kultur. Frankfurt a.M.: Campus-Verlag.

Fehmel, T. (2015). Europäische Integration durch soziale Konflikte. In J. Preunkert \& G. Vobruba (Eds.), Europa - Politik - Gesellschaft. Krise und Integration: Gesellschaftsbildung in der Eurokrise (183-204). Wiesbaden: Springer VS.

Fehmel, T. (2017). Konflikte und Konfliktinstitutionalisierung in der Europäischen Union. In M. Bach \& B. Hönig (Eds.), Handbuch Europasoziologie (162-167). Baden-Baden: Nomos.

Fine, G. A., \& Kleinman, S. (1983). Network and meaning: An interactionist approach to structure. Symbolic interaction, 6(1), 97-110.

Fligstein, N. (2008). Euroclash: The EU, European identity, and the future of Europe. Oxford, New York: Oxford University Press.

Fuhse, J. A. (2009). The meaning structure of social networks. Sociological theory, 27(1), 51-73.

Hahn-Fuhr, I., \& Worschech, S. (2014). External democracy promotion and divided civil society - the missing link. In T. Beichelt, I. Hahn-Fuhr, F. Schimmelfennig, \& S. Worschech 
(Eds.), Challenges to democracy in the 21st century. Civil society and democracy promotion (11-41). Basingstoke: Palgrave Macmillan.

Hirschhausen, U. v., \& Patel, K. K. (2010a). Europäisierung: Version 1.0. Retrieved from http://docupedia.de/zg/Europ.C3.A4isierung?oldid=106413

Hirschhausen, U. v., \& Patel, K. K. (2010b). Introduction. In K. K. Patel \& Martin Conway (Eds.), Europeanisation in the twentieth century: Historical approaches (1-18). New York: Palgrave Macmillan.

Ivan Krastev (2018, July 5). Europa, von Osten aus gesehen. Die Zeit, 9.

Joas, H., \& Knöbl, W. (2004). Sozialtheorie: Zwanzig einführende Vorlesungen. Berlin: Suhrkamp.

Kauppi, N. (2012). Die Politik der Europäischen Union. In S. Bernhard \& C. Schmidt-Wellenburg (Eds.), Feldanalyse als Forschungsprogramm 2: Gegenstandsbezogene Theoriebildung (233-256). Wiesbaden: Springer VS.

KIIS (2006). Press releases and reports - The views and opinions of the Ukrainian population, January 2006. Retrieved from http://www.kiis.com.ua/?lang=eng\&cat=reports\&id $=453 \&$ page $=42 \& \mathrm{t}=3$

KIIS (2012). Press releases and reports - Public perception of integration projects. Retrieved from http://www.kiis.com.ua/?lang=eng\&cat=reports\&id=85\&page=28\&t=3

KIIS (2013). Press releases and reports - Which way Ukraine should go - which union should join? (population preferences for two weeks before the Vilnius summit). Retrieved from http://www.kiis.com.ua/?lang=eng\&cat=reports\&id=204\&page $=22 \& \mathrm{t}=3$

KIIS (2015). Press releases and reports - Geopolitical orientations of Ukrainian Citizens: constants and changes of the last years (February 2012 - February 2015). Retrieved from http://www.kiis.com.ua/?lang=eng\&cat=reports\&id=507\&page $=12 \& \mathrm{t}=3$

KIIS (2017). Press releases and reports - Geopolitical orientations of the residents of Ukraine: September 2017. Retrieved from http://www.kiis.com.ua/?lang=eng\&cat=reports\&id $=720 \&$ page $=3 \& \mathrm{t}=3$

Koselleck, R. (1973). Kritik und Krise: Eine Studie zur Pathogenese der bürgerlichen Welt. Frankfurt a.M.: Suhrkamp.

Kuzio, T. (2006). Civil society, youth and societal mobilization in democratic revolutions. Communist and post-communist studies, 39(3), 365-386.

Lahusen, C., Kousis, M., Zschache, U., \& Loukakis, A. (2018). European solidarity in times of crisis: Comparing transnational activism of civic organisations in Germany and Greece. Österreichische Zeitschrift Für Soziologie, 43(S1), 173-197.

Lahusen, C., \& Pernicka, S. (2016). Editorial. Berliner Journal Für Soziologie, 26(1), 1-5. 
Lewicki, P. M. (2017). EU-Space and the euroclass: Modernity, nationality and lifestyle among eurocrats in Brussels. Bielefeld: transcript.

Liebert, U., \& Trenz, H.-J. (2009). Civil society and the reconstitution of democracy in Europe: Introducing a new research field. Policy and society, 28(1), 1-9.

Liebert, U., \& Trenz, H.-J. (Eds.). (2011). The new politics of European civil society. Routledge studies on democratising Europe: Vol. 6. Milton Park: Routledge.

Lutsevych, O. (2013). How to finish a revolution: Civil society and democracy in Georgia, Moldova and Ukraine. Retrieved from http://www.chathamhouse.org/publications/papers/view/188407

Manners, I. (2003). Europaian studies. Journal of contemporary European studies, 11(1), 67-83.

Mérand, F. (2012). Europäisierung als Formierung europäischer Felder. In S. Bernhard \& C. Schmidt-Wellenburg (Eds.), Feldanalyse als Forschungsprogramm 2: Gegenstandsbezogene Theoriebildung (217-232). Wiesbaden: Springer VS.

Miller, M. (1992). Rationaler Dissens. Zur gesellschaftlichen Funktion sozialer Konflikte. In H.-J. Giegel (Ed.), Kommunikation und Konsens in modernen Gesellschaften (31-58). Frankfurt a.M.: Suhrkamp.

Minakov, M. (2018). Development and dystopia: Studies in post-Soviet Ukraine and Eastern Europe. Soviet and post-Soviet politics and society: Vol. 179. Stuttgart: Ibidem-Verlag.

Mohr, J. W. (1998). Measuring meaning structures. Annual review of sociology, 24(1), 345370 .

Nikolayenko, O. (2007). The revolt of the post-Soviet generation. Youth movements in Serbia, Georgia, and Ukraine. Comparative Politics, 39(2), 169-188.

Padgett, J. F., \& Powell, W. W. (2012). Chapter 1: The problem of emergence. In J. F. Padgett \& W. W. Powell (Eds.), The emergence of organizations and markets (1-29). Princeton: Princeton University Press.

Palyvoda, L. (2014). Civil society organizations in Ukraine: The state and dynamics (20022013): Study report. Retrieved from http://ccc-tck.org.ua/storage/books/2014_report_eng.pdf

Palyvoda, L., \& Golota, S. (2010). Civil society organizations in Ukraine: The state and dynamics 2002-2010. Kyiv: Publishing House <<Kupol>>.

Pernicka, S., \& Lahusen, C. (2018). Power and counter power in Europe. The transnational structuring of social spaces and social fields. Österreichische Zeitschrift Für Soziologie, 43(S1), 1-11.

Polese, A. (2009). Ukraine 2004: Informal networks, transformation of social capital and coloured revolutions. Journal of communist studies and transition politics, 25(2), 255-277. 
Prochasko, J. (2014). Kleine Europäische Revolutionen. In J. I. Andruchovyč (Ed.). Euromaidan: Was in der Ukraine auf dem Spiel steht (113-130). Berlin: Suhrkamp.

Radaelli, C. M. (2003). The Europeanization of public policy. In K. Featherstone \& C. M. Radaelli (Eds.), The politics of Europeanization (27-56). Oxford: Oxford University Press.

Reckwitz, A. (2003). Grundelemente einer Theorie sozialer Praktiken. Zeitschrift Für Soziologie, 32(4), 282-301.

Risse, T., Cowles, M. G., \& Caporaso, J. A. (2001). Europeanization and domestic change: Introduction. In M. G. Cowles, J. A. Caporaso, \& T. Risse-Kappen (Eds.), Cornell studies in political economy. Transforming Europe: Europeanization and domestic change (1-20). Ithaca: Cornell University Press.

The Ukrainian Week (28 February, 2013). EU-Ukraine summits: 16 years of wheel-spinning. The Ukrainian Week. Retrieved from http://ukrainianweek.com/Politics/73494

Tilly, C. (2001). Mechanisms in political processes. Annual review of political science, 4(1), 21-41.

Tilly, C. (2007). Democracy. Cambridge: Cambridge University Press.

Vink, M. (2003). What is Europeanisation? And other questions on a new research agenda. European political science, 3(1), 63-74.

Worschech, S. (2014). Euromaidan goes Parliament: Wer sind "die neuen" ParlamentskandidatInnen? Retrieved from http://www.laender-analysen.de/ukraine/pdf/UkraineAnalysen138.pdf

Worschech, S. (2016). From Maidan to the parliament, from Maidan to the provinces: New paths for Ukrainian civil society. In D. Segert (Ed.), Civic Education and Democratisation in the Eastern Partnership Countries (98-101). Bonn: Bundeszentrale für politische Bildung.

Worschech, S. (2017). New civic activism in Ukraine: Building society from scratch? KyivMohyla Law and Politics Journal, 3, 23-45.

Worschech, S. (2018). Die Herstellung von Zivilgesellschaft: Strategien und Netzwerke der externen Demokratieförderung in der Ukraine. Netzwerkforschung. Wiesbaden: VS Verlag für Sozialwissenschaften.

Zarembo, K. (2017). Substituting for the state: The role of volunteers in defense reform in Post-Euromaidan Ukraine. Kyiv-Mohyla Law and Politics Journal, (3), 47-70. 